\title{
Genetic diversity of Botrytis populations in New Zealand vineyards across seasons and regions
}

\author{
P.R. Johnston, D. Park, D. White and J.P. Wilkie \\ Landcare Research, Private Bag 92170, Auckland 1142, New Zealand \\ Corresponding author: johnstonp@landcareresearch.co.nz
}

\begin{abstract}
Diseases caused by Botrytis spp. are one of the major management issues in New Zealand vineyards. These fungi are genetically diverse across New Zealand's vineyards, with this diversity being reflected in differences in pathogenicity and fungicide resistance between populations. These populations are known to differ in their seasonal and regional distribution. A basic understanding of this diversity, and the factors governing its distribution, are important in developing effective control strategies against Botrytis spp. This study reviews knowledge on the phylogenetic, seasonal and regional distribution of Botrytis spp. in New Zealand vineyards. It confirms earlier reports that populations associated with diseased fruit at harvest often differ from those most frequently detected at flowering. This study also uses microsatellite data to show that the regional differences in diversity seen at flowering are not evident in the populations associated with diseased fruit at harvest.
\end{abstract}

Keywords Botrytis, grapes, $\beta$-tubulin haplotype, transposon, microsatellite.

\section{INTRODUCTION}

Botrytis bunch rot is a major disease of grapes in New Zealand. Our cool maritime climate means that infection can occur throughout the season with disease developing rapidly during periods of high humidity as the fruit ripens (Mundy et al. 2012). Species- and population-specific differences in fungicide resistance and pathogenicity within Botrytis make basic data on genetic diversity important for understanding the disease caused by these fungi (Fournier et al. 2005; Leroch et al. 2013). Previous research (Johnston et al. 2014a) has shown considerable genetic diversity in the New Zealand populations of Botrytis spp. associated with buds and young flowers in spring, with multiple species (both B. cinerea and B. pseudocinerea) and transposon types represented. The genetic variation detected within Botryis cinerea in New Zealand (Johnston et al. 2014a) is similar to that reported from Europe (Walker et al. 2011; Leroch et al. 2013). There also appeared to be a regional pattern to that diversity with $B$. pseudocinerea, and some transposon types and $\beta$-tubulin haplotypes within B. cinerea, being more or less restricted to some wine-growing regions. In contrast, the populations of Botrytis associated with diseased fruit at harvest were genetically more uniform, more or less restricted to the species $B$. cinerea, to the $\mathrm{B} 1$ haplotype within that species, and to 
transposa isolates (i.e. isolates containing both the flipper and Boty transposons). The lack of genetic diversity in the harvest isolates in the limited number of markers investigated meant that it was not possible to determine whether or not the populations of Botrytis cinerea that dominate vineyards at harvest are also genetically distinct between regions. In this study, additional isolates were sampled to test the persistence of regional and seasonal differences observed in the past and used additional markers, microsatellites, to genetically characterise isolates collected from diseased fruit at harvest to test whether they retain the patterns of regional diversity evident in spring.

\section{MATERIALS AND METHODS Sampling}

Samples of Botrytis spp. were collected from vineyards in the Auckland, Gisborne, Hawke's Bay, Marlborough and Waipara regions. Two vineyards were sampled from the Auckland and Waipara regions; for each of these two regions, one vineyard was sampled at flowering and harvest in 2008/09, 2009/10, 2010/11, 2011/12, and 2013/14; the second vineyard was sampled at flowering and harvest in 2011/12. A single vineyard in Marlborough was sampled at harvest in the 2008/09 year, at flowering in the 2009/10 year, then at both flowering and harvest in the 2013/14 year. A single vineyard in Hawkes Bay was sampled at flowering and harvest in the 2008/09 year, and a single vineyard in Gisborne at harvest in the 2008/09 year. Approximately 100 isolates were collected from each vineyard in each season.

\section{Genetic characterisation across regions and seasons}

All isolates were characterised for species and transposon state using the methods from Johnston et al. (2014a,b). Between 20 and 50 isolates from each season/vineyard were also characterised for $\beta$-tubulin haplotype (Johnston et al. 2014a). Some of these data were published by Johnston et al. (2014a).

Using seven of the microsatellites developed for Botrytis spp. by Fournier et al. (2002), we sampled transposa isolates of Botrytis cinerea (the genetic type dominating vineyards at harvest) collected at harvest from vineyards in Auckland, Gisborne, Hawke's Bay, Marlborough and Waipara. Not all the samples were collected in the same year (Table 1). To test the impact of the collecting year, one of the Auckland and one of the Waipara vineyards had two separate samples in both 2009 and 2012. Each vineyard/year population sampled was represented by 22 isolates except from Waipara vineyard 2 with 24 isolates. Data from seven microsatellite markers were analysed using the GenAIEx 6.5 plugin for Excel (Peakall \& Smouse 2006, 2012). The PhiPT

Table $1 \beta$-tubulin haplotype diversity of Botrytis cinerea isolates used in microsatellite experiments and year collected. Haplotype designations from Johnston et al. (2014a).

\begin{tabular}{|c|c|c|c|c|c|c|}
\hline \multirow[b]{2}{*}{ Region and vineyard } & \multirow[b]{2}{*}{ Year } & \multicolumn{5}{|c|}{$\beta$-tubulin haplotype } \\
\hline & & $\mathrm{B} 1$ & $\mathrm{~B} 4$ & B9 & $\mathrm{B} 10$ & $\mathrm{~B} 11$ \\
\hline Auckland, 1 & $2008 / 09$ & 5 & 15 & & 2 & \\
\hline Auckland, 1 & $2011 / 12$ & 11 & 11 & & & \\
\hline Auckland, 2 & $2011 / 12$ & 21 & 1 & & & \\
\hline Gisborne & $2008 / 09$ & 17 & 4 & 1 & & \\
\hline Hawke’s Bay & $2008 / 09$ & 20 & 2 & & & \\
\hline Marlborough & $2008 / 09$ & 22 & & & & \\
\hline Waipara, 1 & $2008 / 09$ & 20 & 1 & & & 1 \\
\hline Waipara, 1 & $2011 / 12$ & 20 & 2 & & & \\
\hline Waipara, 2 & $2011 / 12$ & 18 & 4 & 2 & & \\
\hline
\end{tabular}




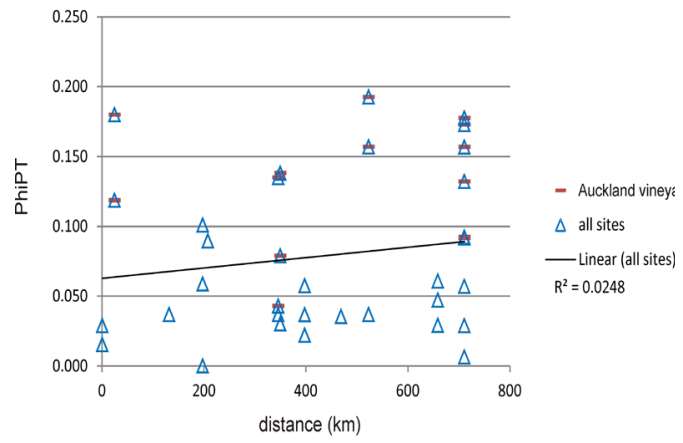

Figure 1 Plot of genetic distance (PhiPT) versus geographic distance $(\mathrm{km})$ based on microsatellite data from Botrytis cinerea isolates collected from seven vineyards from five wine growing regions across New Zealand. The points that compare Auckland vineyard 1 to the other vineyards are indicated with a horizontal bar. Betweenyear comparisons within Auckland vineyard 1 and Waipara vineyard 1 are excluded from the graph. The regression shows a poorly supported relationship between genetic and geographic distance.

values calculated for haploid organisms are the equivalent to Fst values for diploid organisms.

\section{RESULTS}

At flowering in all regions and years sampled, strong differences in regional diversity were evident in the Botrytis populations. Botrytis pseudocinerea was more common in the Auckland region than elsewhere, as were populations of $B$. cinerea containing only the flipper transposon; and at one of the Auckland vineyards the B. cinerea population was dominated by the B $4 \beta$-tubulin haplotype. Populations containing only the Boty transposon were more common in the Waipara region than elsewhere, as were populations dominated by the B9 $\beta$-tubulin haplotype (Table 2).

On diseased fruit at harvest less than $1 \%$ of the isolates were B. pseudocinerea, even in the Auckland vineyards. In all regions and years sampled, 93\% (standard deviation $8.7 \%$ ) of the B. cinerea isolates were transposa (both Boty and flipper transposons present). The Auckland vineyard 1 retained 57\% B. cinerea haplotype B4 (sensu Johnston et al. 2014a) isolates at harvest, whereas all other vineyards were dominated by $B$. cinerea haplotype B1 (82.7\%, standard deviation $12.5 \%)$.

The microsatellite analysis summary statistics for haploid diversity, averaged for the seven microsatellite markers, are provided in Table 3. Most of the genetic variation measured was expressed

Table 2 Percentage of isolates from vineyards sampled at flowering representing B. pseudocinerea, and $B$. cinerea isolates containing only the Boty transposon or only the flipper transposon, and isolates representing either the B4 or B9 $\beta$-tubulin haplotypes (sensu Johnston et al. 2014a).

\begin{tabular}{lccccc}
\hline $\begin{array}{l}\text { Region and } \\
\text { vineyard }\end{array}$ & $\begin{array}{c}\text { Botrytis } \\
\text { pseudocinerea }^{1}\end{array}$ & $\begin{array}{c}\text { Boty only } \\
\text { transposon }^{2}\end{array}$ & $\begin{array}{c}\text { flipper only } \\
\text { transposon }^{2}\end{array}$ & B4 haplotype $^{3}$ & B9 haplotype $^{3}$ \\
\hline Auckland, 1 & 14.4 & 6.2 & 14.1 & 40 & 0 \\
Auckland, 2 & 14.5 & 2.1 & 22.1 & - & - \\
Hawkes Bay & 0 & 2.6 & 4.3 & - & - \\
Marlborough & 0 & 0.8 & 0 & - & - \\
Waipara, 1 & 0.5 & 25.3 & 0.4 & 4 & 48 \\
Waipara, 2 & 2.6 & 54.4 & 0 & 0 & 95 \\
\hline
\end{tabular}

${ }^{1}$ All other isolates are Botrytis cinerea.

${ }^{2}$ Most other isolates are transposa (isolates containing both the flipper and Boty transposons); a few are vacuuma (isolates lacking both transposons).

${ }^{3}$ Isolates were spread across 12 haplotypes, apart from haplotypes B4 and B9, haplotype B1 was the most common and widespread. 
Table 3 Summary statistics for haploid diversity averaged for seven microsatellite markers in Botrytis cinerea populations for nine samples collected at harvest from different vineyards/years.

\begin{tabular}{|c|c|c|c|c|c|c|c|}
\hline \multicolumn{2}{|l|}{ Sample } & $\mathrm{N}^{*}$ & $\mathrm{~N}_{\mathrm{A}}$ & $\mathrm{N}_{\mathrm{F}}$ & $\mathrm{h}$ & uh & $\mathrm{I}$ \\
\hline \multicolumn{2}{|l|}{ Auckland vineyard 1, 2009} & 21.3 & 7.428 & 4.373 & 0.738 & 0.774 & 1.646 \\
\hline \multicolumn{2}{|l|}{ Auckland vineyard 1, 2012} & 21.8 & 5.714 & 3.743 & 0.681 & 0.713 & 1.410 \\
\hline \multicolumn{2}{|l|}{ Auckland vineyard 2} & 22 & 3.714 & 2.470 & 0.552 & 0.579 & 0.991 \\
\hline \multicolumn{2}{|l|}{ Gisborne } & 21.8 & 4.428 & 2.996 & 0.613 & 0.642 & 1.166 \\
\hline \multicolumn{2}{|l|}{ Hawkes Bay } & 22 & 5.000 & 3.043 & 0.571 & 0.598 & 1.166 \\
\hline \multicolumn{2}{|l|}{ Marlborough } & 22 & 4.000 & 2.611 & 0.576 & 0.604 & 1.070 \\
\hline \multicolumn{2}{|l|}{ Waipara vineyard 1, 2009} & 21.8 & 4.857 & 2.670 & 0.558 & 0.584 & 1.098 \\
\hline \multicolumn{2}{|l|}{ Waipara vineyard 1, 2012} & 22 & 3.714 & 2.948 & 0.608 & 0.636 & 1.104 \\
\hline \multicolumn{2}{|c|}{ Waipara vineyard 2} & 24 & 6.571 & 3.345 & 0.645 & 0.673 & 1.385 \\
\hline \multicolumn{8}{|c|}{$\begin{array}{l}{ }^{*} \mathrm{~N} \text { - sample size; } \mathrm{N}_{\mathrm{A}} \text { - number of alleles; } \mathrm{N}_{\mathrm{E}} \text { - number of effective alleles; } \mathrm{h} \text { - diversity; } \mathrm{uh} \text { - unbiase } \\
\text { diversity; I - Shannon's information index }\end{array}$} \\
\hline \multicolumn{8}{|c|}{$\begin{array}{l}\text { Table } 4 \text { Summary AMOVA (Analysis of Molecular Variance) table. Each population represents a se } \\
\text { of } 22 \text { Botrytis cinerea transposa isolates collected at harvest from the same vineyard in the same year. }\end{array}$} \\
\hline Source & df & \multicolumn{2}{|c|}{ SS } & MS & Est. Var. & \multicolumn{2}{|c|}{$\%$ Variation } \\
\hline Among regions & 4 & \multicolumn{2}{|c|}{29.007} & 7.252 & 0.031 & \multicolumn{2}{|c|}{$1 \%$} \\
\hline Among populations & 4 & \multicolumn{2}{|c|}{24.565} & 6.141 & 0.173 & \multicolumn{2}{|c|}{$7 \%$} \\
\hline Within populations & 191 & \multicolumn{2}{|c|}{433.208} & 2.268 & 2.268 & \multicolumn{2}{|c|}{$92 \%$} \\
\hline Total & 199 & \multicolumn{2}{|c|}{486.780} & & 2.473 & \multicolumn{2}{|c|}{$100 \%$} \\
\hline
\end{tabular}

within the populations (vineyards) sampled, with between region differences explaining very little of the variation (Table 4). The year that the isolates were collected appeared to have little impact on the diversity detected. The average pairwise PhiPT values between Auckland vineyard 1 and all other vineyards was 0.133 and the PhiPT value for the 2009 versus 2012 Auckland vineyard 1 samples was 0.013 . The average PhiPT values between Waipara vineyard 1 and all other vineyards was 0.066, and the PhiPT value for the 2009 versus 2012 Waipara vineyard 1 samples was 0.032 .

Auckland vineyard 1 had a high proportion of B. cinerea $\beta$-tubulin haplotype 4 isolates compared to the other vineyards (Table 1), and the microsatellite data showed it to be genetically more distant to the other vineyards. The average PhiPT value for the comparison between Auckland vineyard 1 and all other vineyards was 0.133 , whereas that for the other vineyards excluding Auckland vineyard 1 was $0.040(\mathrm{P}<0.001)$. Genetic distance was poorly related to geographic distance (Figure 1).

\section{DISCUSSION}

At the start of the season during flowering we found strong regional differences in both the transposon status and phylogenetic relationships in populations of Botrytis spp. This genetic diversity was associated with differences in both fungicide resistance and pathogenicity. For example, lab-based pathogenicity tests showed that $B$. cinerea was more pathogenic than $B$. pseudocinerea, and B. cinerea isolates with the $\beta$-tubulin B9 haplotype were less pathogenic than those with the B1 haplotype (Johnston et al. 2014b).

Compared to isolates collected early in the season, the $B$. cinerea populations associated with diseased fruit at harvest are genetically much more uniform and show minimal varation with respect to geographic distance. Therefore, late in the 
season, it is likely that there is little difference in the pathogenic potential of the vineyard populations of $B$. cinerea across the country. One caution is that the results reported here are from a small number of vineyards within only some of New Zealand's wine growing areas. There is still little information on variation between years, minimal data between vineyards within a region, and none between commercial vineyards with different management regimes (e.g. conventional versus organic).

\section{ACKNOWLEDGEMENTS}

We thank Plant and Food Research staff Dion Mundy, Peter Wright, Peter Wood, and Kirsty Boyd-Wilson for assistance with collecting grapes, and for Pernod Ricard and the managers of the Matua Valley, Waiata Estate, and Saints vineyards for supporting this research by allowing us to collect samples. This research was supported through the Plant \& Food Research Low Impact Disease Control programme and the Landcare Research Systematics Portfolio with funding from the Science and Innovation Group of the New Zealand Ministry of Business, Innovation and Employment.

\section{REFERENCES}

Johnston PR, Hoksbergen K, Park D, Beever RE 2014a. Genetic diversity of Botrytis in New Zealand vineyards and the significance of its seasonal and regional variation. Plant Pathology 63: 888-898.

Johnston PR, Wilkie JP, Park D, Cooper JA 2014b. Contract PFR23729 var. Influence of Botrytis cinerea genotype on fungicide sensitivity, pathogenicity and ecology of Botrytis diseases in New Zealand vineyards: Milestone 6. Technical report on objectives 1 and 2. Lincoln, Landcare Research.

Leroch M, Plesken C, Weber RWS, KauffF, Scalliet G, Hahn M 2013. Gray mould populations in German strawberry fields are resistant to multiple fungicides and dominated by a novel clade closely related to Botrytis cinerea. Applied and Environmental Microbiology 79: 159-167.
Fournier E, Giraud T, Loiseau A, Vautrin D, Estoup A, Solignac M, Cornuet JM, Brygoo Y 2002. Characterization of nine polymorphic microsatellite loci in the fungus Botrytis cinerea (Ascomycota). Molecular Ecology Notes 2: 253-255.

Fournier E, Giraud T, Albertini C, Brygoo Y 2005. Partition of the Botrytis cinerea complex in France using multiple gene genealogies. Mycologia 97, 1251-1267.

Peakall R, Smouse PE 2006. GENALEX 6: genetic analysis in Excel. Population genetic software for teaching and research. Molecular Ecology Notes. 6: 288-295.

Peakall R, Smouse PE 2012. GenAlEx 6.5: genetic analysis in Excel. Population genetic software for teaching and research - an update. Bioinformatics 28: 2537-2539.

Walker A-S, Gautier A, Confais J, Martinho D, Viaud M, Le Pêcheur P, Dupont J, Fournier E 2011. Botrytis pseudocinerea, a new cryptic species causing gray mould in French vineyards in sympatry with Botrytis cinerea. Phytopathology 101: 1433-1445. 